\title{
Biochemical

\section{Effect of ginger, Zingiber officinale on sex hormones and certain biochemical parameters of male Wistar rats}

\author{
Ali Afzali and Jamshid Ghiasi Ghalehkandi* \\ Department of Veterinary Medicine, Shabestar Branch, Islamic Azad University, Shabestar, Iran
}

\begin{abstract}
It is well demonstrated that phytoestrogens play an important role in the male reproductive system. So, the aim of the current study was to determine effect of ginger on sex hormones and blood biochemical levels in rat. A 40 male Wistar rats (200-250 g) kept as folk and fed basal chew pellet for a week, then randomly divided into 4 experimental groups. Group 1 was kept as control and fed basal diet (commercial chew pellet) and orally gavage with distilled water. Groups 2-4, provided basal diet and orally gavage of the 100, 200 and $300 \mathrm{mg}$ ginger powder in distilled water, respectively for 4 weeks. At the end of the study, Serum glucose, cholesterol, triglyceride, LDL, HDL, albumin, total protein, urea as well as LH, FSH and testosterone determined. Then animals sacrificed and sperm was collected from epididymis and prepared for spermatozoa characteristics, semen testosterone, LH and FSH levels. According to the results, dose dependent increase observed on spermatozoa forward movement $(\mathrm{P}=0.0001)$. A dose dependent increase observed on sperm viability $(\mathrm{P}=0.0001)$. Orally administration of the 100,200 and $300 \mathrm{mg}$ of the ginger significantly increased serum total protein $(\mathrm{P}=0.0008)$ and decreased glucose $(\mathrm{P}=0.014)$ compared to the control group. Administration of the ginger in a dose dependent manner increased serum triglyceride $(\mathrm{P}=0.01)$ and HDL $(\mathrm{P}=0.0006)$ levels in rat compared to the control group. Orally gavage of the ginger significantly increased semen testosterone levels in comparison to the control group $(\mathrm{P}=0.009)$ while had no significant effect on LH and FSH levels $(\mathrm{P}>0.05)$. No significant effect observed on serum LH, FSH and testosterone levels compared to the control group $(\mathrm{P}>0.05)$. These results suggested ginger improves spermatozoa characteristics and semen hormone level.
\end{abstract}

KEY WORDS: GINGER, LH, FSH, TESTIS, BLOOD BIOCHEMICAL, RAT

\section{ARTICLE INFORMATION:}

*Corresponding Author: ashokdlakhe@gmail.com Received $12^{\text {th }}$ Jan, 2018

Accepted after revision $12^{\text {th }}$ March, 2018

BBRC Print ISSN: 0974-6455

Online ISSN: 2321-4007 CODEN: USA BBRCBA

Thomson Reuters ISI ESC / Clarivate Analytics USA and

Crossref Indexed Journal

NAAS Journal Score 2017: 4.38 SJIF 2017: 4.196

- A Society of Science and Nature Publication, Bhopal India 2018. All rights reserved.

Online Contents Available at: http//www.bbrc.in/

DOI: $10.21786 / \mathrm{bbrc} / 11.1 / 25$ 


\section{INTRODUCTION}

Infertility is one of the major health problems in the world (Ghalehkandi, 2014). Infertility is a multi-parametric phenomenon which more than $30 \%$ of infertilities are related to a male factor (Vincent et al. 2012). Several factors affect spermatogenesis and sperm quality such as drug treatment, chemotherapy, toxins (Adeeyo et al. 2011), air pollutions and insufficient vitamins intake (Barkhordari et al. 2013). It is reported administration of $100 \mathrm{mg} / \mathrm{kg}$ of ginger increased sperm percentage, motility viability, and serum testosterones in rat (Khaki et al. 2009). Based on the literature has a long history in order to fertility regulation (Kooti et al. 2015). Also, there are increasing interests on plant-derived chemicals on the endocrine system and the activity of sexual organs (Kooti et al. 2015).

Ginger (Zingiber officinale R.) is a medicinal plant which is gaining popularity amongst modern physicians (Sakr and Badawy, 2011). The major isolated bioactive ingredients of the ginger are gingerdiol, zingibrene, gingerols, protodioscin, saponins and shogaols (Sakr and Badawy, 2011). Ginger has many therapeutic effects such as antioxidant, antiemetic, antithrombotic, antihepatotoxic, anti-inflammatory and cholagogue (ElMorsy Ibrahim and Al-Shathly, 2015). Ginger relieves nausea and vomiting associated with motion sickness, pregnancy and surgery (Gilani and Rahman, 2005). Ginger has protective role in reproductive toxicities such as cyclophosphamide, cisplatin, malathion and diabetes (Riaz et al. 2017).

It is reported that aqueous extract of ginger $(24 \mathrm{mg} /$ $\mathrm{ml}$ ) has a positive effect on metiram-inhibited spermatogenesis and induced apoptosis in mice (Sakr and Badawy, 2011).Ginger decreases body weight, serum glucose, cholesterol and serum alkaline phosphatase in adult male rats (Bhandari et al. 2005). Many positive effects of ginger on male reproductive system have been reported. It is reported that co administration of ginger $(0.5-1 \mathrm{~g} / \mathrm{kg})$ with lead resumed the plasma testosterone level to near normal levels (Riaz et al. 2011). Since years ago, there are increasing interests focus on verification of pharmacological and physiological actions in ginger as a therapeutic agent (James et al. 2015).

The protodioscin and saponins of ginger increase testosterone and luteinizing hormone (LH) hormone levels as well as libido which can be used in traditional medicine to treat sexual dysfunctions (Morakinyo et al. 2008). Tribestan (patented extract of ginger) increases libido, infertility and menopausal disorders (Imani and Ainehchi, 2014). Also, ginger increases estrogen, pregnenolone and testosterone levels and sexual potency in men (Sabik et al. 2009). Despite researches have been done on effects of the ginger on male reproductive sys- tem, its role on sex hormones in blood and testicular levels is not fully elicited. So, the aim of the current study was to determine effect of the ginger on blood biochemical follicle stimulating hormone (FSH), LH, testosterone levels as well as semen FSH, LH, testosterone hormones in rat.

\section{MATERIAL AND METHODS}

Animals: A 40 male Wister rats (200-250 g) kept as folk and fed basal chew pellet for a week, then randomly divided into 4 experimental groups $(n=10)$. Animals were kept in groups of 8-10 per cage $(45 \mathrm{~cm} \times 30 \mathrm{~cm}$ $\times 15 \mathrm{~cm})$ at a controlled room temperature $\left(23 \pm 1{ }^{\circ} \mathrm{C}\right)$, relative humidity of 55-65\% and were maintained on a light-controlled regime (12-h light cycle, lights on at 07:00 h) according to European Union recommendations for laboratory animals. During the study, all animals had ad libitum access to fresh water. Animals were acclimatized to laboratory conditions for one week prior to experiments. All experimental procedures were carried out during the light phase (10:00-17:00 h) and executed in accordance with the Guide for the Care and Use of Laboratory Animals to Investigate Experimental Pain in Animals (Zimmermann 1983). Animal handling and experimental procedures were performed according to the Guide for the Care and Use of Laboratory Animals by the National Institutes of Health (USA) and the current laws of the Iranian government.

Study design: All animals had free access to basal diet (commercial chew pellet) for a week prior the study. Then animals randomly allocated into 5 experimental groups. Group 1 kept as control and fed basal diet (commercial chew pellet) and orally gavage with distilled water. Groups 2-4, provided basal diet and orally gavage of the 100, 200 and $300 \mathrm{mg}$ ginger powder in distilled water, respectively. All animals provided ad libitum access to the experimental diets based on their groups for 4 weeks. At the end of the sixth week, animals were food deprived for 12 , blood samples were taken, centrifuged at $4^{\circ} \mathrm{C}$ for 10 minutes at $250 \times \mathrm{g}$ and the serum stored at $-20^{\circ} \mathrm{C}$ until assayed. Serum glucose, cholesterol, triglyceride, LDL, HDL, albumin, total protein, and urea were obtained using colorimetric assay using commercial kit (Pars Azmoon Co., Tehran, Iran). Serum concentration of LH and FSH were determined in duplicated samples using radioimmunoassay. Rat FSH and LH kits obtained from Biocode Company-Belgium, according to the protocol provided with each kit. The sensitivities of hormone detected per assay tube were $0.2 \mathrm{ng} / \mathrm{ml}$ and $0.14 \mathrm{ng} /$ $\mathrm{ml}$ for FSH and LH respectively (Khaki et al. 2009). Serum concentration of total testosterone was measured by using a double antibody radioimmunoassay kit 


\begin{tabular}{|l|l|l|l|l|l|}
\hline \multicolumn{2}{|l}{ Table 1. Effect of the ginger on spermatozoa characteristics in rat } \\
\hline Groups & $\begin{array}{l}\text { Forward } \\
\text { movement }\end{array}$ & $\begin{array}{l}\text { Motility without } \\
\text { movement }\end{array}$ & $\begin{array}{l}\text { Without } \\
\text { movement }\end{array}$ & $\begin{array}{l}\text { Dead sperm } \\
(\%)\end{array}$ & $\begin{array}{l}\text { Viability } \\
(\%)\end{array}$ \\
\hline Control & $21^{\mathrm{b}}$ & $22.56^{\mathrm{a}}$ & $60.54^{\mathrm{a}}$ & $70.50^{\mathrm{a}}$ & $29.50^{\mathrm{c}}$ \\
\hline Ginger (100 mg) & $20.70^{\mathrm{b}}$ & $20.80^{\mathrm{b}}$ & $58.30^{\mathrm{a}}$ & $51.95^{\mathrm{b}}$ & $48.05^{\mathrm{b}}$ \\
\hline Ginger (200 mg) & $20.20^{\mathrm{b}}$ & $22.20^{\mathrm{b}}$ & $57.60^{\mathrm{a}}$ & $44.90^{\mathrm{c}}$ & $55.10^{\mathrm{a}}$ \\
\hline Ginger (300 mg) & $37.45^{\mathrm{a}}$ & $31.45^{\mathrm{a}}$ & $30.80^{\mathrm{b}}$ & $44.80^{\mathrm{c}}$ & $55.20^{\mathrm{a}}$ \\
\hline P value & 0.0001 & 0.0001 & 0.0024 & 0.0001 & 0.0001 \\
\hline SEM & 2.99 & 1.99 & 4.30 & 2.15 & 2.15 \\
\hline $\begin{array}{l}\text { SEM standard error of mean. Different letters (a, b and c) indicate significant differences between treatments at each } \\
\text { time (p< 0.05). }\end{array}$
\end{tabular}

(immunotech Beckman Coulter Company-USA). The sensitivities of hormone detected per assay tube were $0.025 \mathrm{ng} / \mathrm{ml}$ (Huang et al. 1995).

Surgical procedure: At the end of the study, rats fasted overnight and were intraperitoneally (i.p) injected with pentobarbital $(40 \mathrm{mg} / \mathrm{kg})$. Peritoneum on each animal was opened by an incision and testes were taken out. Semen samples were collected from the Cauda epididymis and homogenized in 10\% (W/V) ice-cold buffer $(0.1 \mathrm{M}$ phosphate buffer, pH $7.4+150 \mathrm{mM} \mathrm{KCl}$ ). The homogenate was centrifuged at $9000 \mathrm{rpm}$ for $20 \mathrm{~min}$ to obtain a supernatant which was used to determine semen testosterone, LH and FSH levels using radioimmunoassay kits (Biocode Company-Belgium) and (immunotech Beckman Coulter Company-USA) (Huang et al. 1995).

Spermatozoa characteristics: At the end of the study, semen samples were collected from the Cauda epididymis carefully separated from the testis and placed in a Petri dish containing Ham's F10. Epididymal caudal was minced with scissors to release sperm and then was placed in the incubator for 15min (Padmanabhan et al. 2008). Approximately, 10 $\mathrm{LL}$ of the diluted sperm suspension was transferred to each counting chamber of the hemocytometer and allowed to stand for $5 \mathrm{~min}$ (Wyrobek et al. 1983). The cells which settled during this time were counted by a light microscope at 200X magnification (Seed et al. 1996).

Statistical analysis: Data were prepared in excel, analysed with analysis of variance (ANOVA) using SPSS 16.0 for Windows (SPSS, Inc., Chicago, IL, USA) followed by Tukey's post-hoc tests and presented as mean \pm SEM. $P<0.05$ was considered to denote significant differences between groups.

\section{RESULTS AND DISCUSSION}

The results of the ginger on sex hormones and blood biochemical levels in rat are presented in tables 1-5. As seen in table 1, a dose dependent increase observed on spermatozoa forward movement $(\mathrm{P}=0.0001)$. Also, spermatozoa motility without movement significantly increased by administration of the ginger $(100,200$ and $300 \mathrm{mg})$ compared to the control group $(\mathrm{P}=0.0001)$. Also, spermatozoa without movement significantly decreased in rats treated with ginger $(100,200$ and $300 \mathrm{mg})$ compared to the control group $(\mathrm{P}=0.0024)$. A dose dependent increase observed on spermatozoa viability $(\mathrm{P}=0.0001)$ and decreased dead sperm $(\mathrm{P}=0.0001)$.

Effect of the ginger on blood biochemical levels in rat is presented in table 2 . According to the results, orally

Table 2. Effect of the ginger on blood biochemical levels in rat

\begin{tabular}{|l|l|l|l|l|}
\hline Groups & $\begin{array}{l}\text { Total protein } \\
(\mathrm{g} / \mathrm{dl})\end{array}$ & $\begin{array}{l}\text { Albumin } \\
(\mathrm{g} / \mathrm{dl})\end{array}$ & $\begin{array}{l}\text { Glucose } \\
(\mathrm{mg} / \mathrm{dl})\end{array}$ & $\begin{array}{l}\text { Urea } \\
(\mathrm{mg} / \mathrm{dl})\end{array}$ \\
\hline Control & $7.68^{\mathrm{c}}$ & 5.2 & $105.85^{\mathrm{a}}$ & 29.53 \\
\hline Ginger $(100 \mathrm{mg})$ & $8.24^{\mathrm{b}}$ & 5.3 & $113.62^{\mathrm{a}}$ & 41.2 \\
\hline Ginger $(200 \mathrm{mg})$ & $8.82^{\mathrm{a}}$ & 5.46 & $110.62^{\mathrm{a}}$ & 36.95 \\
\hline Ginger (300 mg) & $8.22^{\mathrm{b}}$ & 5.46 & $72.98^{\mathrm{b}}$ & 36.95 \\
\hline P value & 0.0008 & 0.65 & 0.014 & 0.4 \\
\hline SEM & 0.17 & 0.16 & 9.53 & 2.05 \\
\hline
\end{tabular}




\begin{tabular}{|l|l|l|l|l|}
\hline \multicolumn{6}{|l|}{ Table 3. Effect of the ginger on blood lipid profile in rat } \\
\hline Groups & Cholesterol $(\mathrm{mg} / \mathrm{dl})$ & Triglyceride $(\mathrm{g} / \mathrm{dl})$ & HDL $(\mathrm{mg} / \mathrm{dl})$ & LDL $(\mathrm{mg} / \mathrm{dl})$ \\
\hline Control & 253.7 & $51.65^{\mathrm{b}}$ & $46.55^{\mathrm{b}}$ & 23.61 \\
\hline Ginger (100 mg) & 215.5 & $71.73^{\mathrm{a}}$ & $55.65^{\mathrm{a}}$ & 27.65 \\
\hline Ginger (200 mg) & 214.80 & $55.66^{\mathrm{b}}$ & $45.78^{\mathrm{b}}$ & 26.74 \\
\hline Ginger (300 mg) & 218.50 & $62.51^{\mathrm{ab}}$ & $48.78^{\mathrm{b}}$ & 25.98 \\
\hline P value & 0.15 & 0.01 & 0.0006 & 0.60 \\
\hline SEM & 13.7 & 4.22 & 1.66 & 2.18 \\
\hline $\begin{array}{l}\text { SEM standard error of mean. Different letters (a and b) indicate significant differences between treatments at each } \\
\text { time (p<0.05). HDL: high density lipoprotein; LDL: low density lipoprotein. }\end{array}$ \\
\hline
\end{tabular}

administration of the 100,200 and $300 \mathrm{mg}$ of the ginger significantly increased serum total protein levels compared to the control group $(\mathrm{P}=0.0008)$. Serum glucose significantly decreased in rat received ginger $(100,200$ and $300 \mathrm{mg}$ ) compared to the control group ( $\mathrm{P}=0.014)$. No significant difference observed on serum albumin and urea levels in rat treated with ginger in comparison to the control group $(\mathrm{P}>0.05)$.

Administration of the ginger in a dose dependent manner increased serum triglyceride $(\mathrm{P}=0.01)$ and HDL $(\mathrm{P}=0.0006)$ levels in rat compared to the control group. No significant difference observed on serum cholesterol and LDL in animals received ginger than control group (P>0.05) (table 3).

As seen in table 4, orally gavage of the ginger significantly increased semen testosterone levels in comparison to the control group $(\mathrm{P}=0.009)$ while had no significant effect on LH and FSH levels $(\mathrm{P}>0.05)$.

According to the table 5, ginger (100, 200 and 300 $\mathrm{mg}$ ) had no significant effect on serum LH, FSH and testosterone levels compared to the control group ( $\mathrm{P}>0.05)$.

Infertility is one of the major problems which the both male and female related factors are not yet clearly understood (Nassiri et al. 2009). Better understanding of underlying mechanisms in fertility is important to improve diagnosis and treatment (Nassiri et al. 2009). Male fac-

Table 4. Effect of the ginger on semen sex hormone in rat

\begin{tabular}{|l|l|l|l|}
\hline Groups & LH (Iu/l) & FSH (Iu/l) & $\begin{array}{l}\text { Testosterone } \\
(\mathrm{ng} / \mathrm{ml})\end{array}$ \\
\hline Control & 2.54 & 0.24 & $0.75^{\mathrm{c}}$ \\
\hline Ginger (100 mg) & 1.84 & 0.08 & $1.03^{\mathrm{bc}}$ \\
\hline Ginger (200 mg) & 2.13 & 0.09 & $1.2^{\text {ab }}$ \\
\hline Ginger (300 mg) & 1.34 & 0.11 & $1.48^{\mathrm{b}}$ \\
\hline P value & 0.30 & 0.47 & 0.009 \\
\hline SEM & 0.44 & 0.04 & 0.14 \\
\hline $\begin{array}{l}\text { SEM standard error of mean. Different letters (a, b and c) indicate } \\
\text { significant differences between treatments at each time (p< 0.05). } \\
\text { LH: luteinizing hormone; FSH: follicle stimulating hormone. }\end{array}$ \\
\hline
\end{tabular}

tor is involved in 40-50\% of infertility and numerous conditions include in spermatogenesis and sperm quality (Mazaheri et al. 2014). Despite many achievements in modern medicine, side effects of synthetic chemical drugs are still the main problem (Lim, 2016). Hence, there are growing interests to use of herbal medicine due to it possessing lower side effects (Lim, 2016). Ginger is a famous medical plant by anti-oxidant, anti-serotonergic and anti-inflammatory properties (Lim, 2016).

According to the results, dose dependent increase observed on spermatozoa forward movement. Dose dependent increase was observed on sperm viability. In this regard, Khaki et al. (2009) reported administration of the ginger rhizome powder (50 and $100 \mathrm{mg} / \mathrm{kg}$ ) for 20 consequence day increased sperm viability and motility in rat. Orally administration of the Zingiber officinale $(1000 \mathrm{mg} / \mathrm{kg}$ for 28 days) increased epididymal sperm count and motility (Morakinyo et al. 2008).which our results were similar to their findings. Orally administration of the 100, 200 and $300 \mathrm{mg}$ of the ginger significantly increased serum total protein and decreased glucose levels. In this regard, it is reported ginger has anti hyper glycaemic effect by decrease glucose levels in rats (Al-Amin et al. 2006). Despite direct mechanism of action ginger on blood glucose level is not fully elicited, Khan et al. (2003) reported ginger increase

\begin{tabular}{|c|c|c|c|}
\hline Groups & LH (Iu/l) & FSH (Iu/l) & $\begin{array}{l}\text { Testosterone } \\
(\mathrm{ng} / \mathrm{ml})\end{array}$ \\
\hline Control & 4.9 & 0.59 & 1.02 \\
\hline Ginger (100 mg) & 2.52 & 0.34 & 1.44 \\
\hline Ginger (200 mg) & 2.96 & 0.34 & 1.59 \\
\hline Ginger (300 mg) & 2.025 & 0.15 & 2.02 \\
\hline$P$ value & 0.31 & 0.45 & 0.007 \\
\hline SEM & 0.69 & 0.10 & 0.19 \\
\hline \multicolumn{4}{|c|}{$\begin{array}{l}\text { SEM standard error of mean. Different letters }(a \text { and } b) \text { indicate } \\
\text { significant differences between treatments at each time }(p<0.05) \text {. } \\
\text { LH: luteinizing hormone; FSH: follicle stimulating hormone. }\end{array}$} \\
\hline
\end{tabular}


glucose uptake and glycogen synthesis and phosphorylation of the insulin receptor.

Based on the findings of the current study, administration of the ginger in a dose dependent manner increased serum triglyceride and HDL levels in rat. Orally gavage of the ginger significantly increased semen testosterone levels while had no significant effect on LH and FSH levels. In contrast it is reported administration of the 50 and $100 \mathrm{mg} / \mathrm{kg}$ ginger rhizome powder increased testosterones without effects on LH and FSH hormones (Khaki et al. 2009). According to our findings, no effect observed on serum LH, FSH and testosterone levels in ginger-treated rat.

However, Riaz et al. (2017) reported orall administration of the ginger $(1.5 \mathrm{gm} / \mathrm{kg})$ significantly decreased plasma testosterone and LH levels in male rats after lead induced toxicity. Imani and Ainehchi, (2014), reported ginger (20 and $40 \mathrm{mg} / \mathrm{kg}$ ) increased serum $\mathrm{LH}$ while only $20 \mathrm{mg} / \mathrm{kg}$ increased serum FSH levels in rats. In the current study we used 100, 200 and $300 \mathrm{mg}$ of the ginger powder in water. So, perhaps only low levels of the ginger increase the FSH levels which needs further investigations to determine direct cellular and molecular of actions. Ginger extract has androgenic activity which elevates semen testosterone and accumulation of sperm in the seminiferous tubules in rat (Amr and Hamza et al. 2006; Rekha et al. 2010).

As observed in our study, ginger had no effect on serum and semen LH and FSH levels while increased sperm viability and motility. Ginger extract has antioxidant effect by antioxidant enzymes including super oxide dismutase, glutathione peroxides and catalase in rats (Khaki et al. 2009). It seems, ginger increase sperm motility via protective effect (Amr and Hamza et al. 2006). However, because of the limitations of the current study, we were not able to measure antioxidant enzyme levels in serum and testis tissue of the ginger-treated rat. Ginger roots induce antidiabetic activity and enhance male fertility in diabetic rats (Hafez 2010). As observed in this study, ginger decreased serum glucose level and increased sperm viability and movement. Observed effects of the ginger are attributed to its major ingredients including Zingerone, gingerdiol, Zingiberene, gingerols and shogoals (Morakinyo et al. 2008). In conclusion, these results suggested ginger improves spermatozoa characteristics and semen hormone level.

\section{REFERENCES}

Adeeyo OA, Salawu EO, Ola IJ, Saka WA, Adeleke GE, Adeniyi OS. 2011 Effects of Soya Bean Supplements on Fertility in Male Wistar Rats. Maced J Med Sci. Mar 15; 4(1):54-59.

Al-Amin ZM, Thomson M, Al-Qattan KK, Peltonen-Shalaby R, Ali M 2006 Anti-diabetic and hypolipidaemic properties of ginger (Zingiber officinale) in streptozotocin-induced diabetic rats, British Journal of Nutrition, 96(4), 660-666.

Amr A, Hamza AEA. 2006 Effects of Roselle and Ginger on cisplatin-induced reproductive toxicity in rats. Asian J Androl 8: 607-612.

Barkhordari A, Hekmatimoghaddam S, Jebali A, Khalili MA, Talebi A, Noorani M. 2013. Effect of zinc oxide nanoparticles on viability of human spermatozoa. Iran J Reprod Med, 11:767-771.

Bhandari, U., Sharma, J.N. and Zafar, R.1998 The protective action of ethanolic ginger (Zingiber officinale) extract in cholesterol fed rabbits. J . Ethanopharmacol. 61(2):167-171.

El-Morsy Ibrahim AA, Al-Shathly MR 2015 Herbal blend of cinnamon, ginger, and clove modulates testicular histopathology, testosterone levels and sperm quality of diabetic rats. Int. J. Pharm. Sci. Rev. Res., 30(2): 95-103.

Ghiasi Ghalehkandi J. 2014. Garlic (Allium sativum) juice protects from semen oxidative stress in male rats exposed to chromium chloride. Anim. Reprod., v.11, n.4, p.526-532.

Gilani A, Rahman A. 2005 Trends in ethnopharmocology. J. Ethnopharmacol. 100:43-9.

Hafez D. 2010 Effect of extracts of ginger goots and cinnamon bark on fertility of male diabetic rats. J. American Science. 6:940-7.

Huang HFS, Linsenmeyer TA, Li MT, Giglio W, Anesetti R, von Hagen J, et al. 1995 Acute effects of spinal cord injury on the pituitary-testicular hormone axis and Sertoli cell functions: a time course study. J Androl 16:148-157.

Imani AM, Ainehchi N. 2014 Comparison of the effects of methotrexate and ginger extract on reproductive parameters in rats. Crescent Journal of Medical and Biological Sciences 1(3): 103-109.

James W. Daily MY, Da Sol Kim, Sunmin Park. Efficacy of ginger for treating Type 2 diabetes: A systematic review and meta-analysis of randomized clinical trials. 2015;2(1):21115

Khaki A, Fathiazad F, Nouri M, Khaki AA, Jabarikh H, Hammadeh M. 2009 Evaluation of Androgenic Activity of Allium cepa on Spermatogenesis in Rat. Folia Morphol (Warsz) 68: 4551.

Khan A, Safdar M, Khan MMA, Khattak KN, Anderson RA, 2003 Cinnamon Improves Glucose and Lipids of People With Type 2 Diabetes, Diabetes Care, 26, 3215-3218.

Kooti W, Ghasemi-boroon M, Ghafourian M, Asadi-Samani M, Harizi M, Sharafi-Ahvazi N, et al. 2015 The effects of celery leave extract on male hormones in rats. J Herb Med Pharmacol $4(2): 56-60$.

Lim TK. 2016. Zingiber officinale. Edible Medicinal and NonMedicinal Plants. Springer. 469.

Mazaheri M, Shahdadi V, Nazari Boron A. 2014. Molecullar and biochemical effect of alcohlic extract of Alpinia galanga on rat spermatogenesis process. Iran J Reprod Med 12(11): 765-770 
Morakinyo A, Adeniyi 0, Arikawe A. 2008 Effects of Zingiber officinale on Reproductive Functions in the Male Rat. Afr. J. Biomed. Res. 11: 329 - 34.

Morakinyo A0, Adeniyi OS, Arikawe AP. 2008 Effects of Zingiber officinale on Reproductive Functions in the Male Rat. Afr J Biomed Res 11: 329-34.

Nassiri M, Khaki A, Gharachurlu Sh, Ashteani A, Rastegar H, Rezazadeh Sh. 2009 Effects of Ginger on spermatogenesis in Streptozotocin-induced Diabetic Rat. Iranian J. Medicinal Plants 8 (31): 118 - 24.

Padmanabhan S, Tripathi DN, Vikram A, Ramarao P, Jena GB. 2008 Cytotoxic and genotoxic effects of methotrexate in germ cells of male Swiss mice. Mutation Res Genetic Toxicol Environ Mutagenesis 655(1):59-67.

Rekha N, Balaji R, Deecaraman M, 2010 Antihyperglycemic and antihyperlipidemic effects of extracts of the pulp of Syzygium cumini and bark of Cinnamon zeylanicum in streptozotocin induced diabetic Rats. Journal of Applied Bioscience, 28, 1718-1730.

Riaz F, Khan UA, Ayub M, Shaukat S. 2011 Protective role of ginger on lead induced derangement in plasma testosterone and luteinizing hormone levels of male Sprague Dawley rats. J Ayub Med Coll Abbottabad. 23(4):24-27.

Riaz F, Muneera K, Saeed MA. 2017 Effect of high dose ginger on plasma testosterone and leutinising hormone levels in male rats after lead induced toxicity. Journal of Rawalpindi Medical College 21(1): 90-92.

Sabik LM, Abd El-Rahman SS. 2009 Alpha-tocopherol and ginger are protective on Cyclophosphamide-induced gonadal toxicity in adult male albino rats. Basic and Applied Pathology 2: 21-9.

Sakr SA, Badawy GM. 2011 Effect of ginger (Zingiber officinale R.) on metiram-inhibited spermatogenesis and induced apoptosis in albino mice. Journal of Applied Pharmaceutical Science 01 (04); 131-136

Seed J, Chapin RE, Clegg ED, Dostal LA, Foote RH, Hurtt ME, et al. 1996 Methods for assessing sperm motility, morphology, and counts in the rat, rabbit, and dog: a consensus report. ILSI Risk Science Institute Expert Working Group on Sperm Evaluation. Reprod Toxicol 10:237-244.

Vincent P, Underwood SL, Dolbec C, Bouchard N, Kroetsch T, Blondin P. 2012. Bovine semen quality control in artificial insemination centers. Anim Reprod, 9:153-165.

Wyrobek AJ, Gordon LA, Burkhart JG, Francis MW, Kapp Jr RW, Letz G, et al.1983 An evaluation of the mouse sperm morphology test and other sperm tests in nonhuman mammals: A report of the US Environmental Protection Agency Gene-Tox Program. Mutation Res Rev Genetic Toxicol 115(1):1-72.

Zimmermann M (1983): Ethical guidelines for investigations of experimental pain in conscious animals. Pain 16, 109-110. 